\title{
Implementation of Life Cycle Assessment (LCA) and Life Cycle Cost Life (LCC) on Particle Board Wood Furniture Industry in Yogyakarta
}

\section{Implementasi Life Cycle Assessment (LCA) dan Life Cycle Cost (LCC) pada Industri Furnitur Kayu Papan Partikel di Yogyakarta}

Erza Drajat Prabowo, Tatbita Titin Suhariyanto*

Program Studi Teknik Industri, Fakultas Teknologi Industri, Universitas Ahmad Dahlan

Jl. Ringroad Selatan, Kragilan, Tamanan, Kec. Banguntapan, Bantul, Daerah Istimewa Yogyakarta 55191

email: tatbita.suhariyanto@ie.uad.ac.id

doi: https://doi.org/10.31315/opsi.v14i2.6089

Received: $10^{\text {th }}$ November 2021; Revised: $22^{\text {nd }}$ November 2021; Accepted: $1^{\text {st }}$ December 2021;

Available online: $31^{\text {st }}$ December 2021; Published regularly: December 2021

\begin{abstract}
$C V$. Limase Laras is a wood furniture industry in Yogyakarta that has increased production. The company uses electrical energy which contributes to carbon dioxide (CO2) emissions and produces solid waste of sawdust in the production process. On the other hand, with the large assets and high sales of the company, it is important to conduct financial analysis thus the company does not make wrong decisions. Based on these problems, the methods used in this study are Life Cycle Assessment (LCA) to evaluate environmental impacts and Life Cycle Cost (LCC) to analyze life cycle costs. From the LCA analysis, sawdust waste is the highest impact by producing four environmental impacts, namely, global warming (936 $\times 10-2 \mathrm{~kg} \mathrm{CO2-eq),} \mathrm{aquatic} \mathrm{eutrophication} \mathrm{(2.12} \times 10$ $3 \mathrm{~kg}$ NO3-eq), photochemical ozone formation that affects humans (9.04 x 10-3 person*ppm*hours), and photochemical ozone formation that affects plants $(113 \mathrm{~m} 2 \mathrm{UES})$. From the LCC analysis, the NPV value is Rp8,278,512,276.00, which means that the bookshelf production process provides benefits for the company. The $B / C_{n e t}$ value is 37.9, which means that the bookshelf is beneficial. However, the bookshelf production process will be not feasible to continue if the company experiences a $40 \%$ decrease in annual revenue.
\end{abstract}

Keywords: Wood furniture industry, $L C A, L C C$

\section{ABSTRAK}

CV. Limase Laras adalah industri furnitur kayu di Yogyakarta yang mengalami peningkatan produksi. Perusahaan tersebut menggunakan energi listrik yang menyumbang emisi karbon dioksida ( $\left.\mathrm{CO}_{2}\right)$ dan menghasilkan limbah padat serbuk kayu dalam proses produksinya. Di sisi lain, dengan besarnya aset dan tingginya penjualan yang dimiliki perusahaan, maka analisis finansial penting dilakukan agar perusahaan tersebut tidak salah dalam mengambil keputusan. Berdasarkan permasalahan tersebut, metode yang digunakan dalam penelitian ini adalah Life Cycle Assessment (LCA) untuk mengevaluasi dampak lingkungan dan Life Cycle Cost (LCC) untuk menganalisis biaya siklus hidup. Dari analisis LCA, limbah serbuk kayu merupakan memberikan dampak tertinggi dengan menghasilkan empat kontribusi dampak lingkungan, yaitu, pemanasan

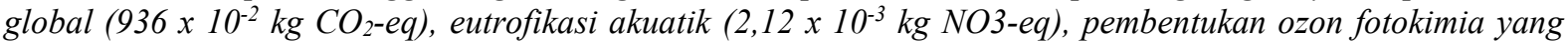
berdampak pada manusia (9,04 × $10^{-3}$ person*ppm*hours), dan pembentukan ozon fotokimia yang berdampak pada tumbuhan (113 m² UES). Dari analisis LCC, didapatkan nilai NPV sebesar Rp.8.278.512.276,00 yang berarti proses produksi rak buku memberikan keuntungan bagi perusahaan. Nilai B/ $C_{n e t}$ sebesar 37,9 yang berarti pembuatan rak buku layak untuk diljalankan. Namun proses produksi rak buku tidak layak untuk dilanjutkan apabila perusahaan mengalami penurunan pendapatan tahunan sebesar 40\%.

Kata Kunci: Industri furnitur kayu, Life Cycle Assessment (LCA), Life Cycle Cost (LCC) 


\section{PENDAHULUAN}

Industri furnitur kayu merupakan industri manufaktur yang mengolah bahan baku mentah berupa kayu menjadi bahan baku produk jadi yang mempunyai nilai tambahan dan manfaatnya. Industri ini sudah lama dikenal masyarakat Indonesia dan berkembang pesat di Indonesia, terutama di Jakarta, Semarang, Solo, Cirebon, Surabaya, Jepara, dan Yogyakarta. Industri furnitur cukup banyak diminati oleh banyak pengusaha karena menjanjikan keuntungan yang cukup besar dan berjangka panjang. Pada tahun 2016 sampai 2019, nilai ekspor furnitur terus meningkat, yaitu sebesar USD1,60 miliar (2016), USD 1,63 miliar (2017), dan USD 1,69 miliar (2018) (Reily, 2019). Pada tahun 2019, industri furnitur termasuk dalam lima industri dengan nilai pertumbuhan terbesar, yaitu sebesar $8,35 \%$. Nilai ekspor industri furnitur meningkat hingga sebesar USD1,95. (kurs Rp 14.200/USD) (Anggraeni, 2020). Tidak mengherankan apabila industri furnitur yang memiliki nilai ekspor ini memberikan pemasukan devisa yang cukup bagi negara. Di sisi lain, dampak lingkungan yang ditimbulkan dari proses produksi industri furnitur juga cukup signifikan.

Proses produksi pada industri furnitur merupakan kegiatan salah satu dari sektor industri yang menggunakan sumber energi yang berlebihan sehingga mengakibatkan dampak lingkungan yang berupa emisi gas rumah kaca (GRK), asidifikasi, dan lain sebagainya. Menurut Kementrian ESDM (2019), sektor industri adalah salah satu pengguna energi tertinggi saat ini. Selain itu, penggunaan energi pada sektor industri tahun ke tahun mengalami peningkatan. Seperti yang disajikan pada Gambar 1.1, proyeksi permintaan energi dari tahun 2018 hingga 2050 akan terus meningkat. Secara umum, industrialisasi yang menggunakan sumber daya alam (SDA) secara berlebihan dapat merusak dan mengganggu keseimbangan ekosistem (Suhariyanto et al., 2020).

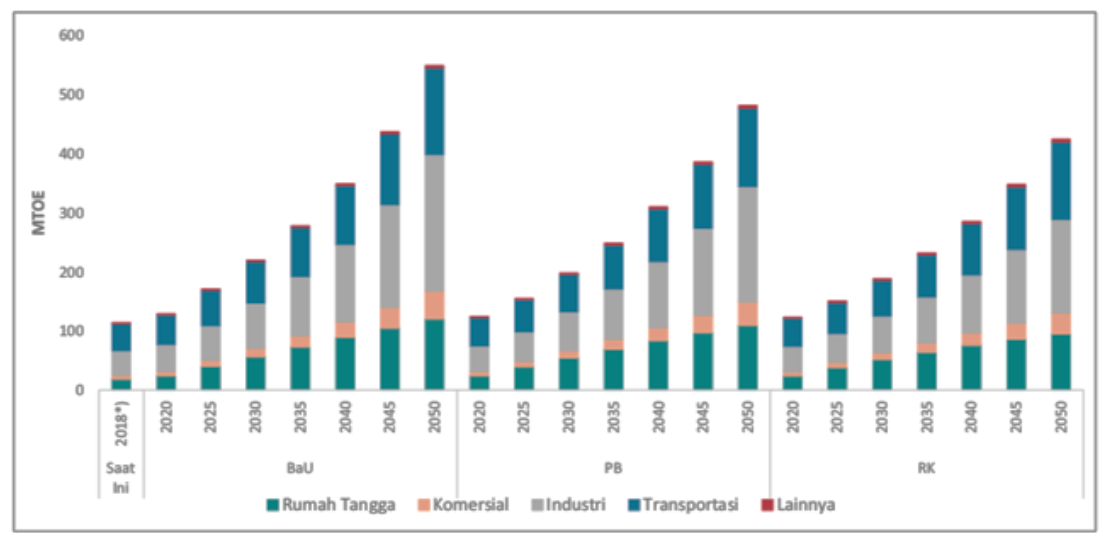

Gambar 1. Penggunaan energi di Indonesia berdasarkan sektor (Kementrian ESDM, 2019)

Salah satu industri furnitur kayu yang mengalami peningkatan produksi adalah $\mathrm{CV}$. Limase Laras yang terletak di Yogyakarta. Industri furnitur ini menggunakan kayu papan partikel sebagai bahan mentah dan sudah melakukan ekspansi pasar hingga ke Eropa. Proses produksi furnitur kayu pada industri ini terdiri dari beberapa tahapan seperti pemilihan bahan baku, perancangan, pemotongan dan perakitan, serta penyelesaian tahap akhir. Dalam menjalankan proses produksinya, CV. Limase Laras menggunakan energi listrik, dimana energi ini akan menghasilkan emisi karbon dioksida $\left(\mathrm{CO}_{2}\right)$ yang mengakibatkan pemanasan global. Selain itu, dampak lingkungan yang ditimbulkan oleh proses produksi CV. Limase Laras merupakan limbah padat berupa serbuk kayu yang dapat mengakibatkan gangguan kesehatan serta gangguan lingkungan. Menurut Chou \& Yeh (2015), kepedulian terhadap meningkatnya GRK sangat dibutuhkan, terutama pada peningkatan emisi $\mathrm{CO}_{2}$.

Penelitian ini memilih produk rak buku sebagai fokus penelitian karena memiliki jumlah pemesanan paling banyak dibandingkan produk lain dengan rata-rata jumlah produksi sebesar 290 produk/bulan. Rak buku berbahan baku kayu jati tersebut akan diekspor ke Jerman. 
Selain kualitas produk, CV. Limase Laras perlu memperhatikan aspek lingkungan guna menembus pangsa pasar Eropa. Menurut GEN (1994), salah satu regulasi yang dikeluarkan oleh Uni Eropa merupakan ekolabel yang berlaku pada produk kayu yang akan dikirimkan ke pasar Eropa. Ekolabel merupakan sertifikasi untuk membuktikan bahwa produk atau jasa tersebut ramah lingkungan dalam katagori tertentu (Santoso, 2014). Oleh karena itu, CV. Limase Laras sesuai dijadikan sebagai objek penelitian karena dapat memberikan gambaran mengenai dampak lingkungan dari proses produksi furnitur kayu dan membantu perusahaan dalam memperoleh sertifikasi ekolabel.

Oleh sebab itu, hasil dari metode Life Cycle Assessment (LCA) diperlukan untuk mengetahui seberapa ramah lingkungan produk tersebut guna mendapatkan sertifikat ekolabel. LCA merupakan suatu metode kuantitatif yang digunakan untuk menganalisis dampak lingkungan suatu produk selama siklus hidup produk berlangsung. Menurut Haedi (2019), LCA secara umum merupakan pendekatan untuk mengukur dampak lingkungan yang diakibatkan oleh produk atau aktivitas mulai dari pengambilan bahan mentah, diikuti proses produksi dan penggunaan, dan berakhir pada pengelolaan limbah. LCA terdiri dari empat langkah, yaitu pendefinisian tujuan dan ruang lingkup, analisis inventori, analisis atau penakaran dampak, dan interpretasi (ISO 14040, 2006).

Selanjutnya, evaluasi biaya siklus hidup pada produk rak buku juga penting dilakukan agar dapat membantu perusahaan dalam mengambil keputusan finansial. Dengan besarnya aset dan tingginya penjualan yang dimiliki CV. Limase Laras, maka analisis finansial sangat penting dilakukan agar perusahaan tersebut tidak salah dalam mengambil keputusan dan mampu mengatasi risiko finansial pada kemudian hari.

Salah satu metode analisis finansial yang sering digunakan adalah Life Cycle Cost (LCC). LCC adalah metode untuk menganalisis nilai ekonomis sebuah produk (Finkbeiner et al., 2010) melalui pendekatan terstruktur dari semua elemen biaya kepemilikan terkait dengan fungsi dan kelebihan kinerja produk. Salah satu hasil dari analisis LCC adalah biaya siklus hidup sebuah produk yang dapat digunakan untuk membantu manajemen dalam pengambilan keputusan dari beberapa opsi yang tersedia (Utama, 2017). Metode ini dilakukan dengan menganalisis nilai parameter-parameter dalam studi ekonomi teknik, seperti suku bunga, biaya investasi awal, pendapatan per tahun, dan biaya operasional.

Pada penelitian yang dilakukan sebelumnya, Haedi (2019) membahas tentang industri furnitur menjadi salah satu sektor industri yang memiliki andil dalam menghasilkan GRK berupa $\mathrm{CO}_{2}, \mathrm{CH}_{4}$, dan $\mathrm{N}_{2} \mathrm{O}$ serta asidifikasi berupa $\mathrm{SO}_{2}$ dan $\mathrm{NO}_{2}$. Penelitian tersebut bertujuan untuk menganalisis daur ulang hidup furnitur melalui identifikasi input dengan menggunakan metode LCA dan memberikan analisis perbaikan dalam upaya penurunan dampak lingkungan. Kategori polutan penyebab GRK yang paling tinggi adalah $\mathrm{CO}_{2}$ sebesar $93 \%$ pada tahun 2015 dan $92 \%$ pada tahun 2016 , berikutnya disusul oleh $\mathrm{CH}_{4}$ sebesar 7\% tahun 2015 dan tahun 2016 sebesar $8 \%$ lalu $\mathrm{N}_{2} \mathrm{O}$ yang paling rendah menghasilkan emisi GRK. Hasil analisis dampak asidifikasi yang tertinggi terdapat pada $\mathrm{SO}_{2}$ yaitu sebesar $73.51 \%$ sedangkan $\mathrm{NO}_{2}$ sebesar $26.49 \%$. Hal tersebut disebabkan oleh besarnya penggunaan energi berupa solar dan listrik. Upaya perbaikan yang diusulkan adalah mengganti bahan bakar solar menjadi biodiesel campuran (B20), pengolahan limbah cair dengan sistem lumpur aktif, dan pengolahan limbah kayu menjadi arang.

Selanjutnya, Hartini et al. (2019) mengevaluasi dampak lingkungan dan menentukan biaya yang timbul dari proses pembuatan meja kayu. Penulis menggunakan metode eco-cost untuk menganalisis biaya yang timbul pada produk meja kayu. Untuk proses produksi, penulis menggunakan LCA dalam cross-leg yang meliputi empat tahap yaitu proses penggergajian, proses konstruksi, proses perakitan, dan proses penyelesaian (finishing). Berdasarkan analisis LCA, dampak lingkungan terbesar berasal dari proses penyelesaian.

Kemudian, Iritani et al. (2015) menilai emisi GRK dari bahan baku pada delapan produk (kursi, meja, kursi sekolah, kursi ruang publik kayu alas logam, kursi ruang publik kayu, meja siswa, meja kabinet, meja kerja dan lemari dapur) dengan menggunakan metode LCA dan dengan siklus hidup cradle-to-gate. Dari perhitungan LCA, diketahui bahwa dampak 
lingkungan yang paling signifikan adalah penggunaan material. Rekomendasi yang diusulkan dalam penelitian tersebut adalah mengganti material yang lebih ramah lingkungan dan menggunakan pembangkit energi yang dapat diperbarui.

Renata (2017) juga menggunakan metode LCA untuk menganalisis limbah dari proses produksi laci Brigthon NS Cinnamon dengan menggunakan metode LCA dengan dampak tertinggi disebabkan oleh penggunaan listrik, lalu diikuti oleh proses penyediaan, distribusi, dan ekstraksi. Untuk meminimalisasi dampak lingkungan, penulis merekomendasikan penggantian teknologi menggunakan sumber energi listrik yang dapat diperbaharui.

Untuk menciptakan produksi serat kenaf yang berkelanjutan, analisis LCA dan LCC juga pernah dilakukan oleh Irawati \& Kurniawati (2020). Dari analisis LCA, tahap pemeliharaan merupakan dampak lingkungan tertinggi dengan nilai sebesar $21,4 \mathrm{mPt}$ dan biaya LCC yang terjadi Rp. 6.088.468.333, NVP dan B/Cnet bernilai positif. Hasil dari analisis sensitivitas menunjukkan bahwa jika terjadi pengurangan produksi lebih dari 6\% maka usaha masih menguntungkan dan dapat dijalankan.

Selain itu, Ambarsari dan Anityasari (2011) juga mengimplementasikan LCA dan LCC pada pemasaran dalam jaringan (daring) dan luar jaringan (luring) untuk produk kustomisasi kaos. Dari penelitian ini, diketahui dampak terbesar untuk pemasaran daring terdapat pada proses penerimaan pesanan sebesar 5,6 Pt, sedangkan untuk pemasaran luring terdapat pada proses distribusi ke toko sebesar 0,16 Pt. Dampak terbesar untuk pembelian daring terdapat pada proses pencarian sebesar $2,71 \mathrm{Pt}$, sedangkan untuk pembelian luring semua proses memberikan dampak sama besar yaitu 0,191 Pt. Hasil dari LCC menunjukkan bahwa pemasaran luring membutuhkan biaya lebih besar daripada pemasaran daring. Namun, dari segi pembelian, pembelian daring membutuhkan biaya lebih besar daripada pembelian luring yang menggunakan media transportasi.

Untuk membantu pemahaman ekolabel pada industri furnitur, Santoso (2014) meneliti perkembangan pemberian ekolabel yang lamban dibanding negara-negara produsen pesaing. Metode yang digunakan adalah survei survey dan wawancara mendalam kepada pemangku kepentingan yang berpeluang memperoleh sertifikat ekolabel. Hasil yang diperoleh dari penelitian ini adalah ekolabel merupakan strategi yang meningkatkan daya saing furnitur di pasar internasional, namun sosialisasi ekolabel di Indonesia masih kurang efektif dan pemahamannya cenderung negatif. Penulis merekomendasikan untuk melakukan sosialisasi terhadap pemahaman ekolabel sehingga industri furnitur dapat bersaing dalam pasar internasional dalam menghadapi tren yang menuntut produk yang ramah lingkungan,

Berdasarkan penelitian-penelitian tersebut, maka metode LCA dan LCC relevan untuk diterapkan pada CV. Limase Laras agar dapat membantu perusahaan dalam mengevaluasi dampak lingkungan dan membantu pengambilan keputusan finansial. Penelitian ini berbeda dengan beberapa penelitian sebelumnya yang hanya fokus pada aspek lingkungan, namun belum melibatkan aspek finansial. Selain itu, implementasi LCA dan LCC pada industri furnitur di Indonesia juga belum pernah dilakukan.

\section{METODE PENELITIAN}

Seperti yang disajikan pada Gambar 2, metodologi penelitian ini terdiri dari beberapa tahap, yaitu identifikasi masalah, perumusan masalah dan tujuan penelitian, pengumpulan data, pengolahan data, analisis hasil, serta kesimpulan dan saran.

\subsection{Pengumpulan Data}

Teknik pengumpulan data yang dilakukan dalam penelitian melalui wawancara dan observasi. Data wawancara diperoleh secara langsung melalui tanya jawab dengan pemilik perusahaan dan para pekerja untuk mengetahui proses produksi rak buku mengenai data bahan baku, energi, biaya investasi awal, biaya operasional dan biaya perawatan mesin hingga biaya sisa dari mesin. Hanya data biaya disposal yang tidak dapat diketahui karena produk rak buku berakhir di negara Jerman. Kemudian, teknik observasi juga dilakukan untuk mengetahui proses produksi secara langsung tentang material dan alat-alat yang digunakan, serta jumlah tenaga kerja.

\subsection{Pengolahan Data}

Pengolahan data pada penelitian ini memiliki dua tahap yaitu metode LCA dan LCC. Ruang lingkup tahap LCA pada penelitian ini 
adalah gate-to-gate yang mencakup proses dari tahapan produksi saja yang akan digunakan untuk menentukan dampak lingkungan.

Tahapan LCA yang pertama adalah penentuan tujuan dan ruang lingkup. Tahap ini dilakukan untuk menentukan tujuan dan batasan siklus hidup produk rak buku dengan data yang diperoleh sebelumnya. Tahap selanjutnya adalah analisis inventori atau Life Cycle Inventory (LCI). Pada tahap ini, kebutuhan energi dan material, limbah padat dan semua keluaran yang dibuang ke lingkungan selama daur hidup rak buku dihitung secara kuantitatif dan dimodelkan dengan perangkat lunak $\mathrm{GaBi}$ Education $\mathbb{C}$.
Tahap ketiga adalah analisis penakaran dampak atau Life Cycle Impact Assessment (LCIA). Pada tahap ini, proses penilaian dampak dari kegiatan produksi rak buku terhadap lingkungan dilakukan berdasarkan hasil analisis inventori yang telah dikumpulkan sebelumnya. Pengolahan data menggunakan perangkat lunak $\mathrm{GaBi}$ Education $\mathrm{C}$ dengan metode Environmental Design for Industrial Product (EDIP) 2003. Tahap terakhir dalam LCA adalah interpretasi yang bertujuan untuk menganalisis hasil dari tahap sebelumnya yang berkaitan dengan tujuan penelitian.

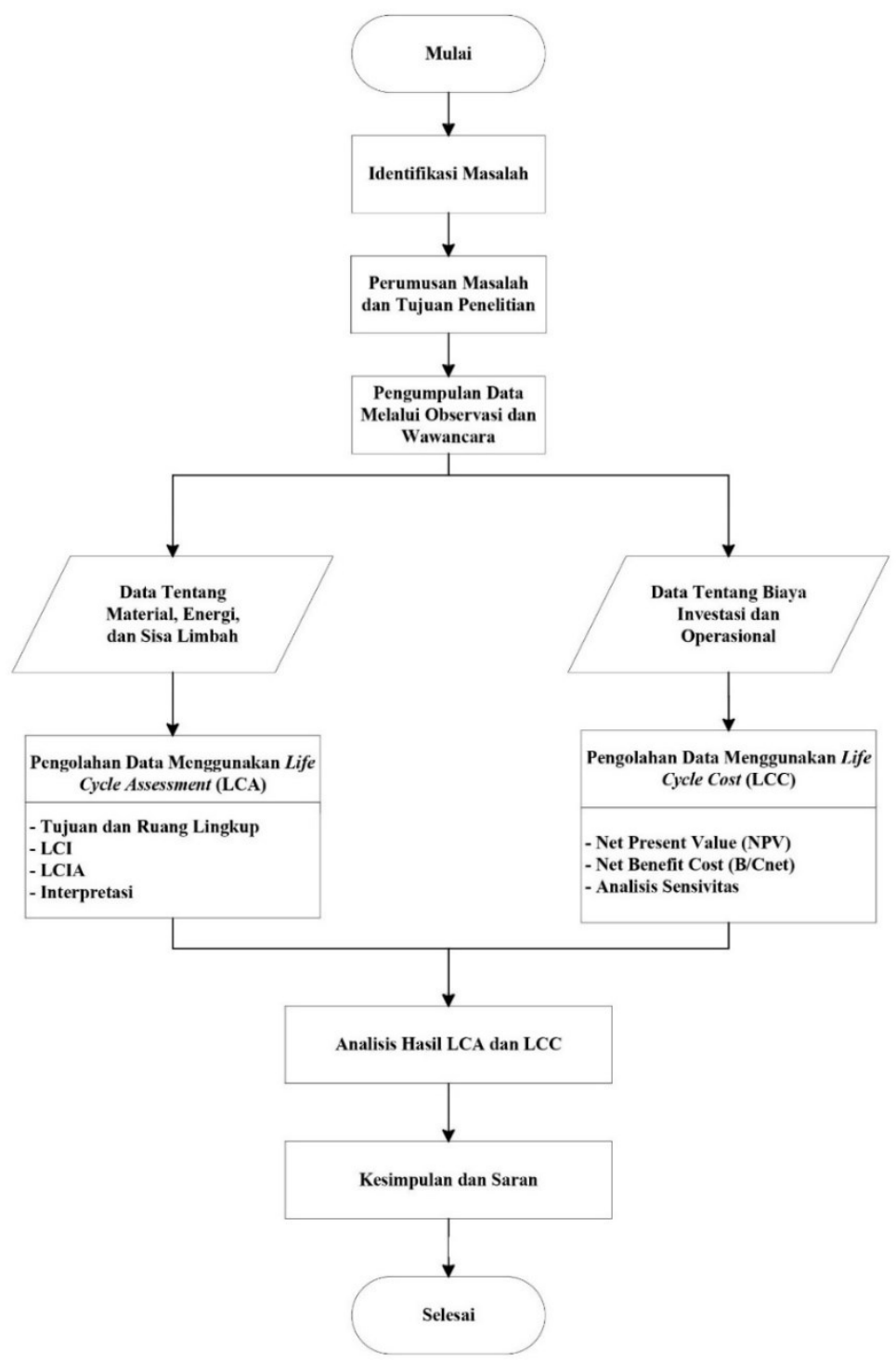

Gambar 2. Diagram Alir Penelitian

Metode selanjutnya yang dilakukan pada penelitian ini adalah LCC. Pada tahap ini, perhitungan biaya menggunakan LCC dilakukan meliputi semua biaya yang digunakan selama proses produksi sampai menjadi produk jadi. Menurut Pujawan (2008), biaya siklus hidup 
terdiri dari biaya investasi, biaya operasional, dan biaya pembuangan (disposal).

Biaya investasi awal pada penelitian ini meliputi pembelian alat dan pembangunan unit industri. Biaya operasional terdiri dari beberapa biaya yang dikeluarkan selama proses produksi. Terakhir, biaya disposal meliputi biaya tenaga kerja untuk memindahkan produk, biaya pengiriman, dan biaya-biaya lain yang berkaitan dengan penghancuran suatu produk. Namun, dalam penelitian ini, perhitungan biaya siklus hanya dilakukan pada perhitungan biaya investasi dan biaya operasional. Hal tersebut dikarenakan produk ini diekspor ke Jerman, sehingga perhitungan biaya disposal sulit dilakukan.

Untuk mengetahui nilai keuangan bersih dan nilai manfaat, maka dilakukan perhitungan Net Present Value (NPV) menggunakan Persamaan 1.

$N P V=\sum_{t=0}^{t=n} C_{t}(1+r)^{2}-C_{0}$

dimana NPV merupakan nilai bersih di masa sekarang, $C_{t}$ merupakan arus kas pertahun pada periode $t, C_{0}$ merupakan nilai investasi awal pada tahun ke-0.

Setelah mendapatkan nilai NPV maka tahap selanjutnya adalah perhitungan Net Benefit/Cost Ratio (BCR), dengan rumus menurut Gittinger (2008) sebagai berikut:

Net $\frac{B}{C}$ Ratio $=\frac{\mathrm{PVB}}{\mathrm{PVC}}$

dimana nilai Present Value Benefit (PVB) merupakan nilai dari pendapatan dan Present Value Cost (PVC) merupakan nilai dimana investasi awal pada tahun ke- 0 .

Tahap terakhir dari LCC yaitu analisis sensitivitas. Analisis ini digunakan untuk mengetahui akibat dari perubahan parameterparameter produksi terhadap perubahan kinerja sistem produksi dalam mendapatkan keuntungan (Kasmir, 2010).

\section{HASIL DAN PEMBAHASAN}

Bab ini memaparkan hasil dampak lingkungan dengan metode LCA dan analisis biaya siklus hidup dengan metode LCC.

\subsection{Analisis Dampak Lingkungan Menggunakan LCA}

Tujuan dalam penelitian ini adalah untuk menganalisis dampak lingkungan dari proses produksi rak buku dan mencari titik kritikal dari keseluruhan proses tersebut. Gambar 2 merupakan objek penelitian yang diamati selama penelitian yang diproduksi oleh perusahaan, sedangkan Gambar 3 merupakan hasil rancangan dan pembongkaran desain (disassembly) yang digambar dengan bantuan perangkat lunak Solidwork16C․ Lingkup yang diamati selama penelitian berlangsung hanya dilakukan pengamatan pada proses produksi yang terdiri dari tiga tahap produksi yaitu, proses pemotongan, proses perakitan, dan proses penyelesaian.

Pada tahap LCI, semua data dikumpulkan dari studi lapangan melalui pengukuran dan wawancara langsung. Data-data tersebut dilakukan dengan cara mengukur massa bahan baku dan produk serta menghitung sumber energi listrik yang digunakan untuk mengetahui input dan output bahan baku dan limbah yang dihasilkan oleh satu produk rak buku. Data ini kemudian dimasukkan ke dalam perangkat lunak GaBi Education( .

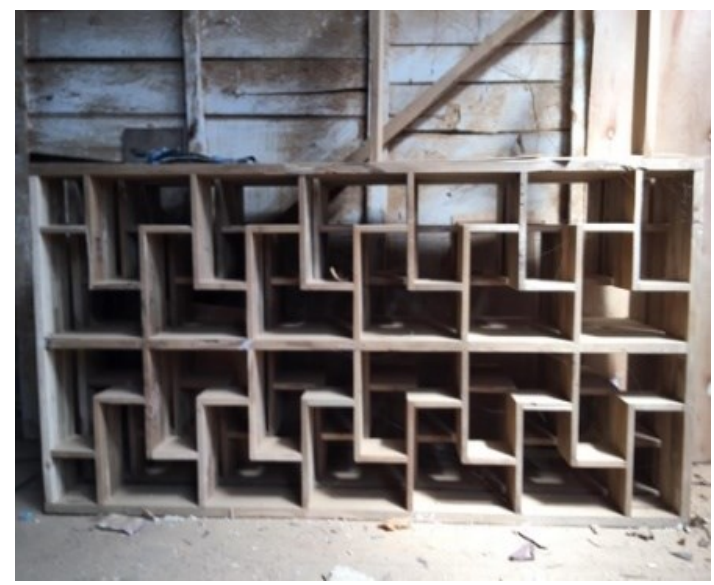

Gambar 2. Produk rak buku

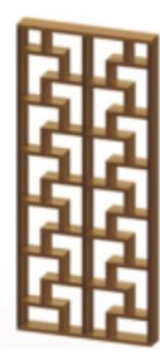

(a)

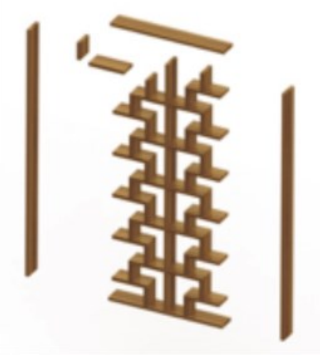

(b)
Gambar 3. Gambaran produk rak buku dengan Solidwork16 $\odot$ 
LCI pada proses pemotongan dapat dilihat pada Tabel 1 dimana proses pemotongan kayu jati dilakukan dengan menggunakan alat gergaji dan penghalusan kayu dengan alat planer kayu dengan sumber energi listrik. Selain itu, tahap pemotongan juga memerlukan kayu jati sebagai material utama produk. Output dari tahap ini berupa potongan papan kayu partikel dan limbah padat berupa serbuk kayu.

Selanjutnya, LCI pada proses perakitan dapat dilihat pada Tabel 2, dimana perakitan rak buku dilakukan secara manual dengan tenaga manusia. Tahap ini menggunakan papan partikel dari hasil pemotongan dan bahan baku penolong kemudian menghasilkan rak buku. Terakhir, oleh karena tahap penyelesaian tidak memerlukan input berupa material dan energi listrik, maka tahap ini tidak memilki aliran input. Aliran input dan output tersebut kemudian dimodelkan dengan GaBi Education(C) untuk dinilai dampak lingkungannya pada tiap proses.

Tabel 1. LCI proses pemotongan

\begin{tabular}{llccc}
\hline Aliran Input & Kuantitas & Jumlah & Unit & Sumber \\
\hline Kayu Jati & Volume & 0,118 & $\mathrm{~m}^{3}$ & Pengukuran \\
Listrik & Volume & 0,03 & $\mathrm{kWh}$ & Perhitungan \\
Aliran Output & Kuantitas & Jumlah & Unit & Sumber \\
Papan Partikel & Massa & 59 & $\mathrm{~kg}$ & Pengukuran \\
Serbuk Kayu & Massa & 6 & $\mathrm{~kg}$ & Perkiraan \\
\hline
\end{tabular}

Tabel 2. LCI proses perakitan

\begin{tabular}{llcrc}
\hline Aliran Input & Kuantitas & Jumlah & Unit & Sumber \\
\hline Papan Partikel & Massa & 59 & $\mathrm{~kg}$ & Pengukuran \\
Paku & Massa & 0,03 & $\mathrm{~kg}$ & Pengukuran \\
Aliran Output & Kuantitas & Jumlah & Unit & Sumber \\
Rak buku & Massa & 54 & $\mathrm{~kg}$ & Pengukuran \\
\hline
\end{tabular}

Setelah melakukan LCI, tahap selanjutnya adalah LCIA. Tahap ini bertujuan untuk menilai dampak lingkungan yang ditimbulkan dari proses produksi rak buku terhadap lingkungan sekitarnya. Tabel 3 merupakan penilaian dampak berdasarkan EDIP 2003 yang memiliki tujuh kategori dampak lingkungan, yaitu,potensi pengasaman (PP), eutrofikasi akuatik (EA), pemanasan global (PG), pembentuk ozon fotokimia yang berdampak pada makhluk hidup (POM), pembentuk ozon yang fotokimia berdampak tumbuhan (POT), penipisan ozon (PO), dan eutrofikasi terrestrial (ET). Setiap kategori dampak lingkungan memiliki unit atau satuan yang berbeda. Dari hasil LCIA, ada tiga proses yang berpotensi memberikan dampak bagi lingkungan, yaitu penggunaan listrik, penggunaan paku, dan hasil limbah serbuk kayu.
Penggunaan material yang berbahan dasar kayu jati tidak menimbulkan dampak lingkungan karena material tersebut sudah termasuk material ramah lingkungan.

Tahap terakhir dari LCA adalah interpretasi data. Terhadap kontribusi dampak lingkungan yang dihasilkan oleh rak buku. Data tersebut diambil dari tahap sebelumnya dengan kategori dampak masing-masing dengan mencari dimana hasil terbesar yang didapatkan dari penggunaan listrik, penggunaan paku, dan serbuk kayu yang dihasilkan. Fokus utama pada penelitian ini pada kategori dampak lingkungan seperti berikut:

\subsubsection{Potensi pengasaman}

Hasil analisis LCIA menunjukan bahwa selama proses produksi rak buku memicu potensi pengasaman dengan total $22,1 \times 10^{-2} \mathrm{~m}^{2}$ 
UES, dimana bahan baku utama paku merupakan besi, sedangkan besi merupakan salah satu kandungan yang berikatan dengan fosfor. Fosfor yang berlebihan di air dapat mengakibatkan penurunan $\mathrm{pH}$ air sehingga menyebabkan potensi pengasaman (Renata, 2017).

\subsubsection{Eutrofikasi akuatik}

Hasil analisis LCIA menunjukan bahwa selama terjadinya proses produksi rak buku menghasilkan eutrofikasi akuatik dengan total sebesar 4,86 x $10^{-3} \mathrm{Kg} \mathrm{NO}_{3}$ eq, dengan kontribusi terbesar terdapat pada dihasilkannya limbah serbuk kayu $2,12 \times 10^{-3} \mathrm{Kg} \mathrm{NO}_{3}$ eq. Hal ini diakibatkan meningkatnya makronutrisi yang terjadi pada ekosistem air akibat serbuk kayu yang memiliki nutrisi nitrogen (Purnama, 2016).

\subsubsection{Pemanasan global}

Hasil analisis LCIA menunjukan bahwa selama proses produksi rak buku menghasilkan potensi pemanasan global sebesar $936 \times 10^{-2} \mathrm{~kg}$ $\mathrm{CO}_{2}$ eq. Hal ini disebabkan oleh penggunaan kayu yang terbilang banyak sehingga menyebabkan penebangan pohon mengalami peningkatan, sedangkan penyebab dari pemanasan global salah satunya adalah penebangan pohon yang menyebabkan emisi gas $\mathrm{CO}_{2}$ meningkat (Yanti, 2016).

\subsubsection{Eutrofikasi terrestrial}

Hasil analisis LCIA menunjukan bahwa selama terjadinya proses produksi rak buku menghasilkan eutrofikasi terrestrial dengan total sebesar 19,4 x 10-2 $\mathrm{m}^{2}$ UES, dengan kontribusi terbesar terdapat pada penggunaan paku sebesar $76,7 \times 10^{-2} \mathrm{~m}^{2}$ UES. Kerusakan tanah diakibatkan oleh adanya logam berat yang menyebabkan tanah mengalami ketidaksuburan dan bahkan menjadi racun bagi tumbuhan (Agustina, 2014).

\subsubsection{Pembentukan ozon fotokimia yang berdampak pada manusia}

Hasil analisis LCIA menunjukan nilai dari pembentuk ozon fotokimia terhadap manusia dengan total sebesar 9,86 $\mathrm{x} 10^{-3}$ person*ppm*hours, dimana kontribusi terbesar terdapat pada hasil dari limbah serbuk kayu dengan nilai $9,04 \times 10^{-3}$ person*ppm*hours. Keberadaan limbah serbuk kayu yang tidak diolah dapat mencemari udara yang menyebabkan pembentukan ozon pada lapisan troposfer. Pembentukan ozon di permukaan tanah troposfer yang disebabkan oleh oksidasi fotokimia dari senyawa Organik Volatil (VOC) dan $\mathrm{CO}_{2}$ dengan adanya sinar matahari dan $\mathrm{NO}_{2}$. Tingginya konsentrasi ozon troposferik di permukaan tanah tersebut dapat menyebabkan gangguan saluran pernafasan pada manusia merusak kesehatan manusia.

\subsubsection{Pembentukan ozon fotokimia yang berdampak pada tumbuhan}

Hasil analisis LCIA menunjukan nilai dari pembentuk ozon terhadap tumbuhan dengan total sebesar $125 \mathrm{~m}^{2}$ UES, dimana kontribusi terbesar terdapat pada hasil dari limbah serbuk kayu dengan nilai $113 \mathrm{~m}^{2}$ UES. Seperti dampak lingkungan yang dijelaskan sebelumnya, adanya pembentukan ozon di permukaan tanah troposfer juga dapat membawa dampak negatif pada ekosistem tumbuhan, seperti punahnya beberapa spesies tumbuhan dan kerusakan ekosistem terestrial.

\subsubsection{Penipisan Ozon}

Hasil analisis LCIA menunjukan nilai dari penipisan ozon dengan total sebesar 5,62 x 10 $0^{-14}$ $\mathrm{kg}$ R11-eq, dimana kontribusi terbesar terdapat pada penggunaan listrik sebesar 5,31 x $10^{-14} \mathrm{~kg}$ R11-eq. Penggunaan listrik merupakan sumber energi utama dari proses produksi pada CV. Limase Laras, sedangkan sumber energi dari listrik merupakan bahan bakar fosil, dimana bahan bakar tersebut menghasilkan gas asam yang menimbulkan masalah penipisan ozon (Edo et al., 2020). 
Tabel 3. LCIA rak buku

\begin{tabular}{|c|c|c|c|c|c|c|}
\hline $\begin{array}{l}\text { Kategori } \\
\text { Dampak }\end{array}$ & & Unit & Total & $\begin{array}{c}\text { Penggunaan } \\
\text { Listrik }\end{array}$ & $\begin{array}{c}\text { Penggunaan } \\
\text { Paku }\end{array}$ & $\begin{array}{c}\text { Limbah } \\
\text { Serbuk Kayu }\end{array}$ \\
\hline $\begin{array}{l}\text { Potensi } \\
\text { Pengasaman }\end{array}$ & $\mathrm{PP}$ & $\mathrm{m}^{2} \mathrm{UES}$ & $22,1 \times 10^{-2}$ & $67,3 \times 10^{-3}$ & $12 \times 10^{-2}$ & $33,8 \times 10^{-3}$ \\
\hline $\begin{array}{l}\text { Eutrofikasi } \\
\text { Akuatik }\end{array}$ & EA & $\mathrm{kg} \mathrm{NO}_{3}$-eq & $4,86 \times 10^{-3}$ & $1,31 \times 10^{-3}$ & $1,44 \times 10^{-3}$ & $2,12 \times 10^{-3}$ \\
\hline $\begin{array}{l}\text { Pemanasan } \\
\text { Global }\end{array}$ & PG & $\mathrm{kg} \mathrm{CO}_{2 \text {-eq }}$ & $125 \times 10^{-1}$ & $178 \times 10^{-2}$ & $133 \times 10^{-2}$ & $936 \times 10^{-2}$ \\
\hline $\begin{array}{l}\text { Pembentukan } \\
\text { Ozon (Manusia) }\end{array}$ & POM & Person*ppm*hours & $9,86 \times 10^{-3}$ & $3,62 \times 10^{-3}$ & $4,54 \times 10^{-3}$ & $9,04 \times 10^{-3}$ \\
\hline $\begin{array}{l}\text { Pembentukan } \\
\text { Ozon } \\
\text { (Tumbuhan) }\end{array}$ & POT & $\mathrm{m}^{2} \mathrm{UES}$ & 125 & $513 \times 10^{-1}$ & $655 \times 10^{-1}$ & 113 \\
\hline Penipisan Ozon & $\mathrm{PO}$ & kg R1- eq & $5,62 \times 10^{-14}$ & $5,31 \times 10^{-14}$ & $1,77 \times 10^{-15}$ & $1,31 \times 10^{-15}$ \\
\hline $\begin{array}{l}\text { Eutrofikasi } \\
\text { Terestrial }\end{array}$ & ET & $\mathrm{m}^{2} \mathrm{UES}$ & $19,4 \times 10^{-2}$ & $56,5 \times 10^{-2}$ & $76,7 \times 10^{-2}$ & $60,8 \times 10^{-2}$ \\
\hline
\end{tabular}

\subsection{Analisis Biaya Siklus Hidup Menggunakan LCC}

LCC pada penelitian ini bertujuan untuk mengidentifikasi biaya-biaya yang terjadi dari proses awal hingga terbentuknya rak buku. Proses ini dilakukan dengan perhitungan biaya investasi dan biaya operasional.Biaya investasi awal untuk mendirikan usaha industri CV Limase Laras sebesar Rp.218.500.000 yang terdiri dari biaya pengadaan tempat dan peralatan. Kemudian, aktivitas operasional untuk satu tahun membutuhkan biaya sebesar Rp.1.140.000.000. Biaya yang dikeluarkan perusahaan untuk perawatan mesin setiap 3 tahun sekali sebesar Rp2.500.000,00 dengan jangka waktu umur mesin selama 15 tahun. Produk rak buku dijual dengan harga Rp850.000,00/produk. Dari penjualan rak buku dengan rata-rata 290 produk/bulan maka perusahaan memiliki pendapatan sebesar Rp246.500.000,00 tiap bulan. Dengan demikian, pendapatan per tahun perusahaan dapat dihitung menjadi Rp2.958.000.000,00. Berdasarkan data tersebut, maka nilai aliran kas dapat dihitung dari selisih antara pendapatan dengan biaya operasional dan perawatan mesin. Terakhir, nilai sisa mesin pada akhir tahun ke-15 diestimasikan sebesar Rp800.000,00.

Selanjutnya, perhitungan NPV dapat dilakukan dengan menggunakan Persamaan (1), seperti yang disajikan pada Tabel 4. Hasil dari
NPV menghasilkan nilai sebesar Rp.8.278.512.276 yang artinya investasi memberikan keuntungan dikarenakan hasil NPV bernilai positif. Perhitungan $B / \mathrm{C}_{\text {net }}$ menggunakan persamaan (2) maka dihasilkan nilai sebesar 37,9 . Nilai dari $\mathrm{B} / \mathrm{C}_{\text {net }}>0$, maka pembuatan rak buku dapat dikatakan layak untuk dijalankan.

Net B/C Ratio $=\frac{8 \cdot 278 \cdot 512 \cdot 276}{218 \cdot 500 \cdot 000}=37,9$

Setelah dilakukan identifikasi biaya dan studi ekonomi bisnis berdasarkan NPV dan $\mathrm{B} / \mathrm{C}_{\text {net }}$, langkah berikutnya adalah analisis sensitivitas. Tabel 5 menunjukan hasil dari perhitungan analisis sensitivitas Analisis sensitivitas pada penelitian ini dilakukan dengan mengubah nilai parameter pendapatan per tahun yang turun hingga $25 \%$ dari pendapatan tahunan yang ditetapkan di awal. Jika pendapatan per tahun mengalami penurunan hingga $40 \%$, maka produksi rak buku mengalami kerugian karena NPV bernilai negatif.

\section{Kesimpulan}

Dari hasil pengolahan data dan analisis, maka dapat ditarik kesimpulan bahwa: analisis dampak lingkungan dengan metode LCA terdapat pada tiga proses, yaitu penggunaan energi listrik, penggunaan paku, dan hasil sisa limbah kayu. 
Tabel 4. Perhitungan NPV dengan tingkat suku bunga $(r)=20 \%$

\begin{tabular}{ccccc}
\hline Tahun (N) & Nilai Aliran Kas & r & $\mathbf{1}(\mathbf{1}+\boldsymbol{r})^{N}$ & Present Value \\
\hline 1 & Rp1.818.000.000 & $20 \%$ & 0,833 & Rp1.515.000.000 \\
2 & Rp1.818.000.000 & $20 \%$ & 0,694 & Rp1.262.500.000 \\
3 & Rp1.815.500.000 & $20 \%$ & 0,579 & Rp1.050.636.574 \\
4 & Rp1.818.000.000 & $20 \%$ & 0,482 & Rp876.736.111 \\
5 & Rp1.818.000.000 & $20 \%$ & 0,402 & Rp730.613.426 \\
6 & Rp1.815.500.000 & $20 \%$ & 0,335 & Rp608.007.277 \\
7 & Rp1.818.000.000 & $20 \%$ & 0,279 & Rp507.370.435 \\
8 & Rp1.818.000.000 & $20 \%$ & 0,233 & Rp422.808.696 \\
9 & Rp1.815.500.000 & $20 \%$ & 0,194 & Rp351.856.063 \\
10 & Rp1.818.000.000 & $20 \%$ & 0,162 & Rp293.617.150 \\
11 & Rp1.818.000.000 & $20 \%$ & 0,135 & Rp244.680.958 \\
12 & Rp1.815.500.000 & $20 \%$ & 0,112 & Rp203.620.407 \\
13 & Rp1.818.000.000 & $20 \%$ & 0,093 & Rp169.917.332 \\
14 & Rp1.818.000.000 & $20 \%$ & 0,078 & Rp141.597.777 \\
15 & Rp1.818.800.000 & $20 \%$ & 0,065 & Rp118.050.072 \\
& Total Present Value & & Rp8.497.012.276 \\
& Total Investasi & & Rp218.500.000 \\
& Net Present Value & &
\end{tabular}

Tabel 5. Hasil analisis sensitivitas

\begin{tabular}{ccc}
\hline Kondisi & NPV & B/C \\
\hline Normal & Rp8.278.512.276,00 & 37,9 \\
Penurunan 25\% & Rp4.825.907.000,00 & 22,1 \\
Penurunan 40\% & - Rp199.009.000,00 & 0,91 \\
\hline
\end{tabular}

Hasil limbah serbuk kayu merupakan dampak tertinggi dengan menghasilkan 4 kontribusi dampak lingkungan dengan nilai masing-masing yaitu, pemanasan global dengan nilai $936 \times 10^{-2}$ $\mathrm{kg} \mathrm{CO}$-eq, eutrofikasi akuatik dengan nilai 2,12 x $10^{-3} \mathrm{~kg} \mathrm{NO}$-eq, pembentukan ozon fotokimia yang berdampak pada manusia dengan nilai 9,04 $\mathrm{x}$ 10-3 person*ppm*hours, dan pembentukan ozon fotokimia yang berdampak pada tumbuhan $113 \mathrm{~m}^{2}$ UES.

Dalam upaya penurunan dampak lingkungan, perusahaan dapat melakukan mengevaluasi proses produksi agar dampak lingkungan lebih terukur dan dapat dilakukan perbaikan secara berkala. Perusahaan direkomendasikan untuk melakukan perbaikan kinerja sesuai dengan peraturan standar pengawasan perusahaan dan menggunakan bahan baku hasil daur ulang kayu jati. Peningkatkan kesadaran pada pengelolaan lingkungan di industri furnitur juga perlu dilakukan. Konsep pengurangan limbah hasil produksi (reduce) dapat diterapkan dalam 
aktivitas produksi agar jumlah limbah yang dihasilkan lebih sedikit (Fakhurozi et al. 2021).

Berdasarkan hasil analisis LCC, proses produksi rak buku dinyatakan layak dan menguntungkan karena nilai NPV positif sebesar Rp.8.278.512.276 yang berarti proses produksi rak buku memberikan keuntungan bagi perusahaan. Nilai $\mathrm{B} / \mathrm{C}_{\text {net }}$ sebesar 37,9 atau $\mathrm{B} / \mathrm{Cnet}>1$. Hal tersebut dapat diartikan bahwa pembuatan rak buku layak untuk diljalankan oleh CV Limase Laras. Namun apabila perusahaan mengalami penurunan pendapatan tahunan sebesar 40\% maka perusahaan mengalami kerugian sebesar Rp199.009.000,00 dan mendapatkan nilai $\mathrm{B} / \mathrm{Cnet}$ sebesar 0,91 , yang artinya proses produksi rak buku tidak layak untuk dilanjutkan.

Saran untuk penelitian selanjutnya adalah melakukan perhitungan dampak lingkungan pada proses produksi yang sudah diperbaiki menggunakan LCA. Selain itu, pengembangan proses identifikasi biaya hingga biaya disposal produk juga dapat dilakukan, sehingga biaya siklus hidup produk dapat dihitung secara lengkap.

\section{UCAPAN TERIMA KASIH}

Penulis mengucapkan terima kasih kepada CV. Limase Laras yang telah membantu proses pengumpulan data penelitian, serta semua pihak yang mendukung terselesaikannya penelitian ini.

\section{DAFTAR PUSTAKA}

Agustina, T. (2014). Kontaminasi Logam Berat Pada Makanan Dan Dampaknya Pada Kesehatan. Teknobuga, 1(1), 53-65.

Ambarsari, N. \& Anityasari, M. (2011). Analisa Life Cycle Assessment (LCA) dan Life Cycle Cost (LCC) pada Pemasaran Online dan Offline pada Produk Kustomisasi Kaos. Surabaya. Institut Teknologi Sepuluh Nopember.

Anggraeni, R. (2020). Kemenperin Optimalkan Potensi Industri Furnitur Nasional. Kementrian Perindustrian RI. https://kemenperin.go.id/artikel/21626/Ke menperin-Optimalkan-Potensi-IndustriFurnitur-Nasional

Chou, J. S., \& Yeh, K. C. (2015). Life Cycle Carbon Dioxide Emissions Simulation and Environmental Cost Analysis for Building
Construction. Journal of Cleaner Production, 101, 137-147.

Edo, R., Vinata, Y., \& Wulandari, Y. (2020). Pembuatan Biodiesel dari Mikroalga Nannochloropsis sp . Menggunakan Metode Transesterifikasi In situ dengan Bantuan Katalis Asam Sulfat. Seminar Nasional Sains Dan Teknologi Terapan, 507-514.

Fakhurozi, A., Suhariyanto, T.T., \& Faishal, M. (2021). Analysis of Environmental Impact and Municipal Waste Management Strategy: A Case of the Piyungan Landfill, Yogyakarta, Indonesia. Jurnal Optimasi Sistem Industri 20(1), 61-71.

Haedi, P, R. (2019). Kajian Penilaian Daur Hidup (Life Cycle Assessment) pada Industri Furnitur (Studi Kasus di PT X, Bogor). Bogor. Institut Pertanian Bogor.

Hartini, S., Wicaksono, P., Prastawa, H., Hadyan, A., \& Sriyanto. (2019). The Environmental Impact Assessment of Furniture Production Process Using the Life Cycle Assessment. IOP Conference Series: Materials Science and Engineering.

ISO 14040. (2006). Environmental Management - Life Cycle Assessment - Principles and FrameworkEnvironmental Management Life Cycle Assessment - Principles and Framework. The International Standards Association.

Irawati, D. Y., \& Kurniawati, M. (2020). Life Cycle Assessment dan Life Cycle Cost untuk Serat Kenaf. Yogyakarta. Jurnal Rekayasa Sistem Industri, 9(3), 213-224.

Iritani, D. R., Silva, D. A. L., Saavedra, Y. M. B., Grael, P. F. F., \& Ometto, A. R. (2015). Sustainable strategies analysis through Life Cycle Assessment: A case study in a furniture industry. Journal of Cleaner Production, 96, 308-318.

Kasmir. (2010). Analisis Laporan Keuangan. Jakarta: PT. Raja Grafindo Persada.

Kementrian ESDM. (2019). Indonesia Energy Outlook. Jakarta: Dewan Energi Nasional.

Pujawan, I. N. (2008). Ekonomi Teknik. Surabaya: Guna Widya.

Purnama, S. G. (2016). Eutrofikasi dan Dampak Bagi Lingkungan Sekitar : Kasus di Danau Buyan. Denpasar. Universitas Udayana.

Renata, S. M. (2017). Analisis Dampak Lingkungan Pada Siklus Hidup Laci dii 
Perusahaan Mebel Kayu Dengan Implementasi Life Cycle Assessment. Malang. Universitas Brawijaya.

Santoso, H. (2014). Ekolabel Sebagai Strategi Meningkatkan Daya Saing Studi Kasus Pada Industri Furnitur Kayu Di Jawa Tengah Dan Yogyakarta. Seminar Nasional IDEC 2014, 241-246.

Suhariyanto, T.T., Faishal, M., Fakhurozi, A., Pajar, R.T., Kadarisman, L.A., Fakihudin, Gusti, S.A.P., Setiawan, A.I., Ilham, A.F., Afifudin, A., Prabowo, H.R., Pratama, D.A., Purwaningsi, L., Nugroho, A.B., Prabowo, E.D., Khasanah, M.N., Arizky, M.I.N., Ningsih, S.W., Juniati. (2020). Produk dari Generasi ke Generasi (pp. 6). Yogyakarta: Deepublish.
Sutrisno. (2015). Studi Kelayakan Bisnis. Yogyakarta. EKONISIA FE UII..

Utama, M. (2017). Life Cycle Cost Analysis. Media Utama Indonesia. https://www.mediaedutama.co.id/lifecycle-cost-analysis.html

Yanti, N. D. (2016). Penilaian Kondisi Keasaman Perairan Pesisir dan Laut Kabupaten Pangkajene Kepulauan pada Musim Peralihan I. Makasar. Universitas Hasanuddin. 